\title{
Education for sustainable development: current discourses and practices and their relevance to technology education
}

\author{
Walter Leal Filho $\cdot$ Evangelos Manolas $\cdot$ Paul Pace
}

Published online: 6 November 2008

(C) Springer Science+Business Media B.V. 2008

\begin{abstract}
Technology education is a well-established field of knowledge whose applications have many ramifications. For example, technology education may be used as a tool in meeting the challenges of sustainable development. However, the usefulness of technology education to the sustainability debate as a whole and to education for sustainable development in particular, has largely been overlooked in the past. Indeed, there is a paucity of academic studies which examine the contribution technology education may provide to education for sustainable development. On the basis of the need to address this knowledge gap, this paper reviews the state of affairs in relation to education for sustainable development and considers its links and appropriateness to technology education. A further objective of this paper is to present examples of initiatives and existing practices around the world, drawing partly from the results of the 1st European Conference on Education for Sustainable Development held in Greece in October 2007, as well as from other initiatives undertaken in Europe and North America. Finally, some measures that may be adopted in order to enhance the contribution of technology education to education for sustainable development are outlined.
\end{abstract}

Keywords Education for sustainable development · Initiatives and practices · Secondary and higher education · Transformative pedagogies

W. Leal Filho $(\bowtie)$

Research and Transfer Centre, Applications of Life Sciences, Faculty of Life Sciences, Hamburg University of Applied Sciences, Lohbruegger Kirchstraße 65, Hamburg 21033, Germany

e-mail: leal@international-projects.eu

E. Manolas

Department of Forestry and Management of the Environment and Natural Resources, Democritus University of Thrace, 193 Pantazidou Street, Orestiada, Greece

P. Pace

Centre for Environmental Education and Research (CEER), Faculty of Education, University of Malta, Room 327, Msida MSD 2080, Malta 


\section{A review of the state of affairs in relation to sustainable development and education for sustainable development and the links with technology education}

Sustainability is currently one of the most widely used words in the scientific field as a whole and in the environmental sciences in particular. The evolution of such a concept has been progressing steadily over the past three decades (Leal Filho 2000). Until the late 1970s, the word "sustainability" was only occasionally employed and in most cases to refer to ways through which forest resources should be used. At present, the expression "sustainability" is being used as synonymous to words such as "long-term", "durable", "sound" or "systematic", among others. Indeed, outside the context of the English language, sustainable development (SD) is very often referred to as "durable development" in French, while word-by-word translations are found in the German (nachhaltige Entwicklung), Spanish (desarrolo sustenible) and Portuguese (desenvolvimento sustentável) languages. Although such differences in the expression may suggest differences in meaning, there is a common aspect, namely, the fact that sustainability is about long-term perspectives as opposed to short-term goals.

A key question that is posed over and over again by people all over the world is what does sustainable development really mean? Some examples which illustrate the variety of meanings are:

- the systematic, long-term use of natural resources-as defined in the Brundtland Report—so that these are available for future generations (here referring to country and local policies)

- the modality of development that enables countries to progress, economically and socially, without destroying their environmental resources (here referring to country/ national policies)

- the type of development that is socially just, ethically acceptable, morally fair and economically sound (here referring to the social ramifications of development)

- the type of development where environmental indicators are as important as economic indicators (here referring to the close links it bears with economic growth).

Despite this variation in the meanings attributed to sustainable development, a number of commonalities can be identified. In general, sustainability:

(a) refers to long-term prospects with ecological, political, economic and societal implications

(b) is a dynamic process, whose implementation depends on due consideration of social processes of which individual engagement and participation are essential elements and

(c) depends on concerted efforts and cannot be based on action by a few countries or local actors if it is to be implemented on a global level

Many other variants to the definitions outlined in this paper may be listed and are indeed used by different organizations, taking into account their political perspectives and institutional aims. The World Conservation Union (IUCN), which in liaison with the United Nations Environment Program (UNEP) and the World Wide Fund for Nature (WWF) produced "Caring for the Earth" (IUCN et al. 1991) for example, suggested at the time that the expression "sustainable development" be replaced in some contexts by "sustainable living", since although the suffix "development" is associated with governments and refers to a government's responsibilities, the word "living" is closer to an individual's life and personal choices (Leal Filho 2000). Table 1 outlines some factors which influence 
Table 1 Some factors which influence attitudes towards sustainability

\begin{tabular}{ll}
\hline Knowledge & $\begin{array}{l}\text { Information on the meaning of sustainability and its implications } \\
\text { Background }\end{array}$ \\
$\begin{array}{l}\text { The nature of his/her training often influences an individual's degree of receptivity in } \\
\text { relation to sustainability }\end{array}$ \\
Experience & $\begin{array}{l}\text { Previous experience with environmental and social affairs facilitates understanding on the } \\
\text { role of sustainability }\end{array}$ \\
Perception & $\begin{array}{l}\text { The integrated view of environmental, political and economic elements enables a broader } \\
\text { perception of sustainability }\end{array}$ \\
Values & $\begin{array}{l}\text { Differing from the previous factors due to their high degree of complexity, an individual's } \\
\text { values often determine whether his/her attitudes are favorable or otherwise }\end{array}$ \\
Context & $\begin{array}{l}\text { Sustainability is not only related to ecological factors per se, but also entails consideration } \\
\text { of, for example, economic, political and social matters. However, links with the latter } \\
\text { are often ignored by schools and universities }\end{array}$ \\
\hline
\end{tabular}

Modified from Leal Filho 2000

attitudes towards sustainability and describe their implications. An understanding of such factors is important in order to allow the integration of sustainability concepts and ideas in the framework of both policies and school/university curricula.

In the international debate on sustainability, emphasis needs also to be given to education for sustainable development (ESD). The publication of Agenda 21 (United Nations 1992) as a whole and Chap. 36 (Promoting education, public awareness and training) in particular and its subsequent endorsement by over one hundred governments, reiterates the value the international community affords - at least in principle - to sustainability and to education for sustainable development.

The various definitions of the term "sustainable development", are reflected in the variety of proposals which have emerged for education for sustainable development, e.g., Environmental Education (EE) (UNESCO 1980); Earth Education (van Matre 1990); Environmental and Development Education (EDE) (UNCED (United Nations Conference on Environment, Development) 1992); Environmental Education for Sustainability (EEfS) (Tilbury 1995); Education for Sustainability (EfS) (Huckle and Sterling 1996); Education for a Sustainable Future (ESF) (UNESCO 1997); Education as Sustainability (EaS) (Foster 2001); Sustainable Development Education (SDE) (Smyth 2002).

The general impact of this explosion of terms has tended to concentrate attention on finding the right definition (hence the emphasis on content matter) rather than developing the right framework (i.e., the promotion of new methodologies) to ensure that the principles of ESD are deeply rooted in all education sectors-especially the formal one (Leal Filho and Pace 2006). This diversity of definitions may also be indicative that ESD is continuously evolving to meet emergent needs and hence rather than being solely concerned with content it is primarily concerned with process. Consequently, a strategy aimed at firmly establishing ESD within formal education should be characterized by questions that lead to a radical rethink and possible restructuring of existing traditional educational structures and norms of conduct to cater for ESD needs.

In order to discuss the parallels between education for sustainable development and technology education - an issue dealt with under different perspectives in other papers in this special issue - it may be useful to refer to a study performed by Gross (2000) with research teams in the US, Canada, Australia and Germany. This provides a useful overview of the current understanding about sustainability and its links with education, technology and economics, across developed countries. Gross and his researchers asked groups of 
adults in the four countries a set of questions about sustainability — with some ramifications for areas such as technology and economics. Their answers may enable political leaders and the public to deal appropriately with sustainable development issues in technology education and business. The following three paragraphs discuss the three questions and the range of responses to them in turn.

When asked to identify the main obstacles to implementing the principles of sustainable development in educational and economic systems, respondents were of the opinion that the causes and consequences of unsustainable practices are not analyzed, i.e., there was little insight and readiness to change unsustainable practices. In addition, due to the fact that the principles of sustainability and the concepts behind this approach had not been explained sufficiently, most people still did not understand it. Moreover, respondents suggested that political leaders have missed the chance to address the general public on this issue from the very start. Since there is a general lack of strong community approaches to SD due to human selfishness and other ego-driven values, people in our societies concentrate more on the world of work rather than on the social and environmental worlds. In addition, political leaders do not know how or simply do not have an interest to motivate people to become an active part of civil society. The majority of political leaders and members of the educational administration are not really interested in implementing SD in education (and business) because they do not understand SD at all. They do not recognize the necessity for a change or even see the need for financial resources. Budget cutting is their normal praxis! Finally, with regard specifically to school systems, one of the key obstacles is the lack of synergy between the sciences where each science is being thought of as if there is no link with other teaching subjects. Curricula were deemed as not being trans-disciplinary enough.

The second question asked what qualities young students need for coping with the challenges of economic, ecological and cultural globalization. Answers stressed the need for students to re-direct their learning strategies, not towards enrichment by information, but towards knowledge which is focused on objectives and accompanied by abilities and skills, also in technology. Respondents replied that students should have qualities such as human values; perspectives such as respect and tolerance; a sense of caring for the environment and others, and the personal and vocational skills to be self-reliant and not become a victim of circumstances. Moreover, they need to understand the strategic issues facing them at the local and the global levels and how each of these issues regarding the environment, the economy and society's well-being are interdependent. In this context, fundamental skills such as critical and ethical thinking, problem-solving, consensusbuilding and conflict resolution as well as the knowledge that science, business, and politics must work together are essential components of an ESD program.

Finally, when asked what are the next important steps to overcome the previous deficits and deficiencies in education and the economy, the most common answer stressed that politicians should commit their constituents and themselves to both a global and a local solution to SD and that the general public should be addressed and linked to the whole process of implementing SD. The only basis for a change is the public's understanding of their role in this process. Respondents also stated that new legislative frameworks should be created that would incite the principle actors in the economy to understand that their field is intertwined with the environment, technology and society's well-being. There is a need to create new spaces for dialogue and education between society's stakeholderslegislation will not be enough.

An overriding conclusion that can be made from the responses provided in Gross's (2000) study is that there must be intensive co-operation among communities, schools and 
teacher education institutions in order to pursue ESD and technology education in an integrated way. This means that teacher education institutions have to be reformed and students trained for a sustainable future, where the role of technology is clearly outlined. Moreover, the answers to the questions posed by Gross and the variety of views reflected on sustainability mean that we are still a long way from making this important concept part of everyday life, especially in respect of linking sustainable development with technology education.

The next section of this paper outlines some of the initiatives taking place in different parts of the world, at the school and university level, that exemplify existing practices where ESD and technology education have been integrated.

\section{Examples of initiatives and existing practice}

What is a Best Practice? What distinguishes a Best Practice from any other practice in technology education for sustainability? Is a Best Practice related to content, instructional strategies, classroom management, organizational structure and even organizational change, program effectiveness, student learning, teaching effectiveness, or the unique and creative initiatives of individuals? Maybe it's all of these practices and even much more.

For the purposes of this paper, a Best Practice in technology education for sustainability is a human created and directed activity whose purpose is to bring about purposeful change in student learning, teaching effectiveness, and program effectiveness in an exemplary way. It should be noted that it may be very difficult to identify all the Best Practices in technology education for sustainability being practiced today, and that those which will be identified may even be subject to debate. But debate and discourse are healthy endeavors and the Best Practices selected in this paper may provide the impetus for healthy discussions in this field. It is the purpose of this paper to not only identify and profile some of the outstanding practices in technology education for sustainability today, but also to explain their rationale. In addition, the examples which follow were selected on the basis of the following criteria:

- they were innovative

- they were detailed

- they were recent

- they were geographically diverse and

- they originated in different educational levels and systems.

\section{Introducing technology education in schools}

Enriching school curricula with explicit opportunities for multiple expression modes that are valid in a variety of classroom contexts will not only help meet the need for future technology innovators, but also redefine the role of school education itself, and potentially the cultural identity of the society. Technological innovations involve multidisciplinary perspectives and multiple skills, and appropriate training beginning at the school level is the key to creating experts and citizens capable of innovations. Introducing technology into the curriculum of school pupils is also important because of the propensity of this age group to engage in technological activity with an enthusiasm, curiosity and lack of inhibition that creates an optimum opportunity for development. Pupils' sheer excitement, 
wonder and enthusiasm for the world around them make for an era of rapid development. The more people in this age group engage in technological activity, the more their confidence in their technological abilities may be established.

Three examples below are taken from Martin and Martin (2006) who identified them as examples of best practices in USA schools. They are related to the issues of energy and recycling, and the examples demonstrate how such issues can be effectively addressed in technology education classes. A number of cross-disciplinary links are highlighted in these examples.

\section{Green technology}

Students at Greencastle Middle School in Greencastle, Indiana are presented with a problem to create a piece of furniture made entirely from recycled and "unorthodox" items. Working in small teams, students must incorporate at least three different materials to make their "new" piece of furniture. Since students are not allowed to purchase materials, their solution must be made entirely from scrounged materials. As a result, students have created a wide assortment of furniture pieces from a variety of recycled items such as tire rims, old tarpaulins, foam insulation, and broken products. For example, one team recently made a fold-up bed from old closet doors.

Students begin the unit by conducting intensive research about recycling. During this process, they learn about how important it is to recycle and where some of the greatest problems in recycling occur including furniture recycling. Students collect materials and bring them to the "Green Technology" classroom/laboratory where they design, build, and evaluate their solutions over a period of several weeks.

Through this activity, students begin to ask a lot of good questions about design and recycling, as well as technical questions about how to combine the materials using tools and machines. They learn to become more independent because of the open-ended nature of the problem and the need for them to show initiative in identifying and locating the materials that they need to solve the problem. Since they work in small groups, they must also develop teamwork skills in order to have a successful solution to the problem. This activity helps them to understand and interact with technology in their world and see that they can be part of the solution to the recycling problem by being creative, technological problem-solvers (Martin and Martin 2006). Furthermore, the emphasis on long-term use of materials promotes the importance of sustainable living, a key concept in technology education for sustainability.

\section{Exploring alternative energy production}

The purpose of this technology education course at South Windsor High School in Connecticut is to explore how society will meet its future energy needs. The course uses textbooks, articles, and a series of experiments to explain a variety of energy related technologies.

The goal is to provide students with the opportunity to explore energy production and distribution systems in order to develop an appreciation for the social, economic, and environmental impacts of these technologies. Students work with energy conversion systems that are environmentally friendly and renewable in an effort to inform themselves about potential solutions that can meet their future energy needs. In the process students identify academic strengths and weaknesses that relate to the design professions. The 
course provides each student with the knowledge and skills necessary to use technology as a creative tool.

This course provides students with the opportunity to explore energy and electrical power production. Students first explore current energy resources and production systems through selected readings and discussion. They then conduct an energy audit of their homes and develop an appreciation for how much energy their family consumes. They also examine what it costs their family to maintain their current level of energy consumption. The students then cost-out an alternative energy system that could provide an adequate amount of power to their homes. Finally, the students study the environmental impacts associated with energy production systems. During this portion of the course, they explore Fuel Cell Power Plants and track power production data from an on site UTC Fuel Cells PC 25 Power Plant.

Students learn how fuel cells use chemical processes to produce electricity by examining and testing a variety of models that use various fuels to produce electricity. They perform experiments with hydrogen/oxygen fuel cells and methanol fuel cells and they graph performance data and produce reports that demonstrate their understanding of this technology.

The culminating experience for the students is the design and production of a small scale fuel cell. Students reverse engineer a single cell fuel cell to examine all of the components and develop ideas for their design. Students then use PTC Pro/Desktop computer aided design software to develop a design as a group project. Each student is responsible for some component of the fuel cell and a 3D CAD model and engineering drawings of the design are created. Components are tested in CAD to insure that they fit together and then machined on a CNC machine to produce the final components. The finished prototype is then tested with the electrolyser and meters used in previous experiments to test the commercially manufactured fuel cells. Students compare their results to those of the commercially produced fuel cell and produce a final presentation that documents the design and production process (Martin and Martin 2006).

Through this activity students develop an understanding of the dynamic nature of energy production and consumption, appreciate the difficulties facing real life designers, involve themselves in decision making processes and acquire a concern for the future over an important environmental issue.

\section{Energy transformation devices}

Students are asked to design an energy transformation device that is contained within a $2^{\prime} \times 2^{\prime}$ footprint and created entirely from recycled materials. The device must incorporate all six simple machines to transfer motion from the input to the output. The unique aspect of this device, however, is that each team's design must integrate with the next team's design so that all the energy transformation devices can be combined into one large energy transformation device (transferring energy from the first device to the last device in consecutive order). This engineering design activity is adapted from one developed and promoted by Project Lead the Way and known as the SMET device (using Science, Math, Engineering, and Technology to create a Simple Machine Energy Transformation Device).

Students' designs must be developed on paper prior to beginning construction, with the design scanned into the computer and serving as the "legally binding design document". Students are penalized if they vary the design without first filing an engineering design change notice. Throughout this design activity, students must keep a journal and document their design process, including all necessary calculations pertaining to the problem 
(e.g., force, weight, distance). Students are encouraged to design and build appealing solutions (e.g., no tape allowed) that solve the problem in the most creative manner. They mostly use hand tools, but they have access to other special tools to enhance their design (e.g., a laser cutter to engrave or cut parts).

Through this activity, students learn about energy transformations, kinetic and potential energy, mechanisms, and more. This is an exciting challenge for students and one that helps them begin to value the importance of planning ahead and relying upon scientific and mathematical information or research to inform design solutions. Students get a sense of how products are designed in the real world and the importance of accuracy in transforming designs from paper to final product. Students often refer to this Rube Goldberg influenced idea as the "coolest project!" (Martin and Martin 2006).

\section{Introducing technology education for sustainability in institutions of higher learning}

Sustainability, sustainable development, and sustainable design, manufacturing, and production all provide a conceptual framework within which many technical, environmental, and social issues can be discussed and explored (Marsall and Toffel 2005). Because of their extensive experience in teaching, training and research, academic institutions of higher learning can provide for our future teachers, policy makers, and community and business leaders the expertise and vision needed to foster a sustainable future.

Five examples below illustrate approaches at the higher education level. Although they are not directly related to technology education (TE) teacher training (except one case study), they examine a variety of approaches that can be accommodated within TE teacher training or adapted to the classroom environment in schools.

Advancing sustainability in an engineering program, University of Canterbury, New Zealand

Since the work of engineers has an impact on biophysical resource supplies and ensuing wastes, they are critical players for ensuring that ecosystems can support current and future civilizations. The course description which follows highlights how important it is to motivate and educate student engineers about the importance of understanding and wisely using ecosystem goods and services, alongside technical material, to ensure survival of the interdependent biotic and fiscal economies. Such a holistic approach to sustainable development is important because it recognizes interrelationships and interdependencies between people, the environment and the economy as core requirements of sustainable development.

The BE (Agricultural Program) began in 1967 at the University of Canterbury and it is taught jointly with Lincoln University. The number of students enrolling in the undergraduate natural resources engineering degree has markedly increased since 2002, perhaps partly as a result of more awareness in primary and secondary schools about the importance of environmental sustainability. A range of assignments are given to students over the course of study.

In the second year (co-taught with the civil engineering degree in 2006, students were assigned the task of performing a hypothetical ecohydrology site assessment as part of an Assessment of Environmental Effects (AEE) for a proposed large residential development. The scenario given was contextual, current and required systems thinking. Its purpose was for students to interrelate material they learnt across the course (ENNR 203), particularly 
identifying the interdependence of ecosystems, hydrology (water supply and quality) and economic developments. Subtle indications that the land was previously contaminated and the nearby lake was a protected wetland meant that students were forced to think more deeply about whether or not their assessment should support the proposed development and what considerations must be recognized.

In the third year, students specializing in the natural resources engineering degree are given the task of calculating their net household ecological footprint over a period of ten weeks in a course entitled Ecological Engineering 1 (ENNR 305). They are provided with a complex spreadsheet which contains (along with guidelines) many variables from which to assess their impacts. These include a calculation of their impact from travel, food consumption, household construction and energy use, amongst other parameters.

In the 4th year, the same sub-set of natural resources engineering students become more engaged with ecological sustainability and engineering through their year-long project course (ENNR 429) aligned with industry, local and regional councils and consultancies. All projects are real world problem-solving exercises integrated into the community in some form. Recent projects have included: an energy audit for a local primary school with recommendations toward energy efficiency; quantification of (previously unknown) stormwater contaminants into the University campus waterways and proposing ecologically integrated sustainable design solutions for mitigating the ecological impacts, soil conservation and nutrient retention solutions in degraded soils by using waste amendments (O’Sullivan and Painter 2007).

Integrating sustainability into chemical and biological engineering curricula, Department of Chemical and Biological Engineering, University of British Columbia, Canada

In the 4th year elective course on pollution prevention engineering (CHBE 484) in the Department of Chemical and Biological Engineering, University of British Columbia, students are required to undertake a term project or to write a term paper, preferably in a group of three students on the broad topics of pollution prevention and sustainability.

Three types of projects can be considered by the students. Type one is to propose a green engineering project, including the outline of the problem, the approach to be adopted, and the significance of the work. Over the years, various industrial processes have been covered by this type of term paper, with representative ones including: emission inventory in the Lafarge Cement Plant; reducing fuel consumption in the Lloydminster Refinery; pollution prevention analysis on the Burnaby incinerator; crude oil storage tank emissions and their controls.

The second type of project is to carry out a small green engineering project for a community, a process or a specific unit operation or product. Students are allowed to form a team of three people. Over the years, students have been working on various hands-on projects related to regional energy issues such as an energy exchange network for municipal waste incinerators, life cycle analysis of fuel cell vehicles, energy efficiency in local green houses, and specific issues such as storm-water management or waste solvent recycling. To identify potential projects related to sustainability across the campus and the region, the Department closely collaborated with the University Sustainability Office and the Department of Health, Safety and Environment. Working side by side with sustainability and environmental officers at UBC, students learned more about how to apply what they learned in class to serve the community. Some of the projects include: pollution prevention in campus; pollution prevention strategies implemented to the UBC's heating 
system; recycling systems in the Gage Residence; development and evaluation of alternative waste solvent streams; waste audit of the Chemical Engineering Building and anaerobic farm waste digestion for rural $\mathrm{BC}$ farms.

The third type of project is to critically review a successful pollution prevention or green engineering project, including its approaches, techniques adopted and analysis. The students are encouraged to identify shortcomings and then to propose possible improvements to the project based on green engineering principles or to propose how to conduct a similar approach locally. Some of the representative examples include: chlorine substitution in the pulp bleaching sequence; review of Air Care Program; Dynamotive's Bio Therm and Bio-Oil: an example of pollution prevention; life cycle analysis of common furnaces; life cycle assessment of electric dryer versus paper towels (Bi Tony 2005).

Case studies of a technology teacher education program, Faculty of Education, Griffith University, Australia

Since 2004 a number of courses within the Bachelor of Technology Education program have been re-designed and re-structured to focus on different elements of Education for Sustainability (ES). To develop coherent learning experiences these changes have been planned on the basis of a theoretical analysis of what ES means for the technology education area. A curriculum development framework was created that was based on general considerations such as the ways sustainability could be conceptualized, the nature of knowledge, 'eight sustainability principles' for the university and particular issues specific to the area of technology education such as ES aims for technology education and principles of sustainable design. A number of achievements within this program include: across-course approaches; links to communities outside the university; effective/practical approaches to sustainability issues; and close relationships between research and teaching.

For example, the notions of SD and technology education have been introduced through (i) pedagogical courses such as: Technology Education: The Context; Technology Education: Curriculum Development; Issues in Technology Education; and (ii) through the practical, design-based courses such as: Product Design (Wood); Product Design (Plastics); The Major Project. ES is the major focus for Product Design (Plastics), one out of six major research themes for Issues in Technology Education; one out of three contexts for design in the Major Project. Through the $4 \mathrm{~h}$ per week over 13 weeks of the Product Design (Plastics) course, students are asked to design and make a board game for children of a particular age. Students are asked to design and manufacture all of the game components including a container to package the game. The emphasis is on both the development of design and make skills and on learning about eco-technologies and the broad concepts of sustainable development. Lectures cover a wide range of topics including plastics for a sustainable future, recycling, product analysis, properties and uses of plastic and board game design as well as manufacturing techniques, design and safety issues. Through the process of teaching, the lecturer observes students' reactions to the issues discussed and the approaches they used for their design. This provides the basis for classroom reflections and discussions.

Another initiative was the establishment of a research group within the Faculty of Education Research Centre that included academics from technology, vocational and mathematics education to focus on the conceptualization of ES and ES research at primary and secondary school levels to provide case study materials and other resources for university students and staff. Research Honors students have been involved as research assistants and as researchers for Honors research projects. The research projects were 
focused at regional/national and international levels. The results of these research projects have been used in the program.

Another component of the integrated approach is the co-operation of academic staff involved in the Bachelor of Technology Education with local schools. On a number of occasions staff members have approached local schools for joint development and delivery of ES projects, monitoring students' and teachers' involvements, attitudes and learning. On one occasion a primary school approached staff members asking for help with their ESD project for Year 7 students.

The close links with community can also be seen in several projects with the Queensland museum. For example, in 2006 two 4th year students, through their final project course, designed and made a model of a sustainable house appropriate for the South East Queensland environment and developed teaching materials to be used with this model. Currently, any Queensland teacher can book this kit through the museum website and use it in the classroom (Pavlova 2007).

\section{Curriculum greening, Universidad Politecnica de Catalunya (UPC), Barcelona, Spain}

The following example shows that including environmental and SD aspects in all subjects of an engineering education program is possible; it highlights the importance of training engineers not as pure designers of technology but as "social" engineers, and it demonstrates that faculties are interested in introducing SD in the curricula. However, it also shows that to achieve such goals is a laborious and time-consuming process requiring both bottom-up and top-down approaches.

In November 1996, the Universidad Politecnica de Catalunya (UPC) approved its first environment plan in order to introduce environmental commitments within the university. The plan covered six major areas of university life: undergraduate education, postgraduate education, research, university life, awareness raising and coordination (Capdevila et al. 2002). The main and most ambitious objective in the area of education was the curriculum greening of all the subjects offered at UPC. To start working on this, the first step was to prepare a collection of manuals (one for each school or faculty) to assist students (and their lecturers) to incorporate the study of environmental impact in their final theses. The second step was to involve the schools in order to produce a School Curriculum Greening Plan (SCGP) for each school. These SCGPs had three main phases:

- to establish the profile of environmental knowledge that a student needs to learn

- to design the optimal 'green' curriculum and

- to establish an action plan at school level.

Apart from the lecturers of each school, the process for producing these SCGPs also involved professional associations and former students of the schools. They helped to establish a curriculum greening team (and responsibilities) in almost every school that produced an SCGP. Once the main schools at UPC had produced the SCGP, the next step was to work with the 'horizontal structure' of departments, in order to produce a Department Greening Plan (DGP) for each one. Unlike the SCPGs, the DGPs covered not only curriculum greening, but also research and department life. The idea was to work with a structure closer to the reality of the lecturer, who, ultimately, is the key actor in the curriculum greening process. The main phases of the DGP were:

- to establish the basic environmental aspects that should define the department's actions 
- to determine the priority greening routes at undergraduate and postgraduate education level and

- to establish a short-term action plan.

The quantity of information generated and the need to disseminate it through UPC and other universities and education centers has led to the development of the Virtual Resources Centre on Curriculum Greening in Technology (e-ambiT). Another important project was the establishment of a new subject. This subject, 'Environment and technology: environmental education in engineering', was developed in digital format (virtual learning), and is now being offered as an optional subject. The 60 hour course was coordinated by the UNESCO Chair for Sustainability at UPC, and besides its educational content it also gives students the opportunity to participate in a virtual discussion forum on sustainability. More than 700 students have chosen this subject since September 2000 (Ferrer-Balas et al. 2002).

Engineering education and sustainable development, Delft University of Technology, The Netherlands

Since September 2000, students at Delft University of Technology are able to specialize in sustainability in relation to their discipline during the last years of their education. The requirements are the completion of work which is clearly sustainability-oriented and the successful completion of a selection of three to five sustainability-oriented specialization courses. The selection has to cover some 400 study hours plus a thorough sustainability analysis of the subject through the student's thesis (Mulder and De Werk 2004).

One of the sustainability-oriented specialization courses is called 'Technology and Global Development'. In this course, the role of technology in developing countries is analyzed. The so-called 'boat week' is a compulsory course of the 'sustainability-oriented specialization'. In this course, students from various disciplines take a boat trip together for one week. On this trip they take an intensive course that includes lectures, excursions, workshops, brainstorming session, videos, discussions and role-playing games. Since nobody can leave the boat and withdraw from the process, a pressure cooker situation is created, in which interaction of faculty and students, from different disciplines, is guaranteed. The participating students are generally very critical and are engaged in vigorous discussion, even during the breaks. During the course, students become aware of the specific contribution they can make to sustainable development, based on their different backgrounds. Furthermore, they broaden their scope and realize that discussion and cooperation with people from other disciplines can lead to different and often better solutions (Mulder and De Werk 2004).

An important result of the 'boat week' was the establishment of the Organization of Students for Information and Reflection on Interdisciplinarity and Sustainability (Osiris) (Mulder and De Werk 2004). Students who followed the 'boat week' course started this knowledge and communication platform. They organize various activities, including lectures, workshops and political debates. They also have a website with a forum at which various discussions take place. In addition, every six weeks the Technology Assessment group organizes a lunch meeting with a speaker. This speaker is someone from within the University who speaks about methods and experiences on education or research related to sustainability. Both students and staff join the meetings and exchange experiences during the discussions. 


\section{Education for sustainable development and technology education: a symbiotic relationship}

The set of case studies presented above provides tangible evidence of two inter-related characteristics of technology education at the various levels of education: (a) that it is not just a know-how subject, but a know-why subject (Seemann 2003); and (b) that it provides students with the opportunity to resolve problems and hence extend human capabilities. Consequently the implication is that technology education has to be learner centered and interdisciplinary in approach to integrate various concerns. After reviewing over 300 technology education documents from Australia, Williams and Keirl (2001) elicited a list of common targets (summarized below) that students are expected to reach when following a technology education course:

- a conceptual understanding of the dynamic nature of technology

- a concern for the future characterized by a good quality of life

- an appreciation of the demands of social, economic and environmental systems on technological change

- an awareness of the students' impact and control over their environment

- a critical perspective

- the development of a range of transferable skills and competencies

- a creative, innovative and flexible approach to problem-solving

- a responsible and ethical attitude towards decision making and

- an ability to identify and adapt to change.

These targets have also been addressed - in varying degrees - by the case studies cited. The question that remains to be explored is: what pedagogical principles are conducive toward achieving these targets? All the case studies clearly show evidence that the merging of technology education and ESD has proven to be symbiotic in nature, i.e., both areas benefiting from the association. The major reason for this successful merge is the compatibility of the educational principles and methodologies of both areas.

Even a cursory review of the principles of environmental education-as proposed by the Tbilisi 1977 Conference (UNESCO 1980) and subsequently confirmed at the Moscow 1987 Congress (UNEP 1987), the Thessaloniki 1997 Conference (Scoullos 1998) and reproposed as Education for Sustainable Development (UNESCO 2005)—shows a striking similarity with the educational objectives of technology education particularly if its focus of action revolves around the integration of economic, social and environmental perspectives.

Through ESD principles on the one hand, technology education dealt with issues that were more relevant to the learner's environment making the learning experiences of central importance to the learner and enhancing motivation. On the other hand, through technology education, ESD ensured its place in the curriculum. This might not seem such a great achievement in countries where ESD's inclusion in educational programs is mandatory by national policies. However, in countries where this is still not the case, this symbiotic infusion of ESD in the curriculum offers a tangible (and at times the only) access route for ESD principles in formal education. What follows is a reflection of how this symbiotic infusion was specifically achieved in the examples proposed.

All case studies were characterized by the presentation of problem-solving situations (a basic feature of technology education), but the significant difference was the type of problem chosen by the course designers. Rather than opting for 'textbook' problems characterized by 'typical' solutions, course designers opted for problems related to 
sustainable development. By their very nature, being set within a social-economic-environmental framework, such problems demand a holistic treatment and 'design \& make' takes on a whole new perspective that is more in line with reality. Within the safe confines of their learning program, students were provided with opportunities to face the dilemmas that developers have to face in their day-to-day work and learn (first hand) what taking sustainable decisions involves and the implications of such decisions.

Working with these open-ended problems encouraged students to explore and use a range of disciplines and processes with the aim of finding the most suitable solution. Besides responding to a variety of different students' learning styles and needs, this methodology promotes flexibility and reflection on the adequacy of the decisions made concerning design and manufacture. Inherent in this methodology is the stimulus urging students to think and act outside the box, hence refuting accepted norms of unsustainable behavior as possible ways forward. Preparing students in this manner is an investment in a workforce that, while working within certain parameters, believes that sustainable development is a viable option.

The symbiotic association of ESD and technology education has addressed the factors identified in Table 1 by effectively placing the learner and his/her personal development at the centre of the learning program. Besides being concerned with the cognitive dimension of learning (i.e., gaining factual knowledge), this association allowed learners to be changed in a meaningful way during the learning program. This was achieved through the development of social and psychomotor skills as well as affective attributes exemplified by the development of responsibility and commitment toward sustainable development. This is what the educational literature refers to as transformative learning (e.g., King 2005) where the focus is not just the transformation of students into functional citizens, but also the transformation of the learning institutions themselves.

The important role that higher education institutions-in particular teacher education institutions - have in preparing a cohort of individuals who live and promote a sustainable lifestyle, has been the recurrent theme of major environmental education (or ESD) events (e.g., UNESCO 1980; UNESCO-UNEP 1988; Scoullos 1998). The development of this ethic is dependent on transdisciplinarity, wide conceptualizations and a pedagogy that is primarily learner centered and the major spirit of technology education. Due to their long established traditions, formal education institutions tend to be exactly the opposite: being more concerned with narrow monodisciplinary structures that promote the transmission of subject content (Pace 2000). The development of a sustainable development ethic depends on whether "... knowledge is interrelated to personal behavior and social values, and if the learner experiences ethical demands in decision making" (Schleicher 1996, p. 32). As has been demonstrated by the case studies, the implication is that effective ESD at formal education institutions is dependent on a change in praxis; and change is not always welcome. Consequently, alternative methodologies are viewed with suspicion and need to be acknowledged and legitimized within the institutions' administrative structures for them to proceed.

Moore (2005a) identifies four barriers (disciplinary, competition, misdirected evaluation and unclear priorities) that university based ESD programs have to face (see also Gross 2000). Moore also refers to corresponding pathways to change: i.e., research and teaching that is transdisciplinary; collaborative and transformative learning; participatory evaluation; and a vision of sustainability that is owned by all the administrative strata of the institution. These pathways seem to have been successfully addressed by the symbiotic association model proposed by the case studies cited in this article. 
The case studies showed that ESD was achieved in various contexts, via technology education programs, through the employment of diverse and integrated subject matter, diverse learning settings and a varied pedagogy that promotes participatory learning and higher-order thinking skills (Tal 2005). Educational institutions, particularly teacher education institutions, need to create, what Moore (2005b) calls, space for pedagogical transformation that supports transformative learning. Moore goes on to highlight that this is not just a physical space, but also a time for learners to engage in reflection, dialogue and action. These transformative pedagogies transform learners (and therefore classes and learning communities) into inquisitive, reflective, experienced and critical thinking individuals - the basic unit of a sustainable society.

\section{Conclusions}

As argued in this paper, there are some strong links which associate education for sustainable development with technology education, even though such links have been largely overlooked in the past. Therefore, as part of the efforts towards establishing ESD within formal education and in catering for a rethink and restructuring of existing practice, due consideration to the contributions from technology education can play an important role.

If one looks at the design and technology curriculum area, one can see that in developing and applying knowledge and understanding of materials among students or in developing, planning and communicating ideas that take into account technical, social, aesthetic and environmental concerns, great synergies between the goals of education for sustainable development and technology education exist.

From a practical perspective, there is a need to build bridges among these two wellestablished concepts. This is, however, not an easy undertaking since various pre-conditions need to be met. One of them is the pressing need for training teachers, so that they are able to and feel comfortable with the idea of integrating both concepts and hence provide a more favorable environment for learning.

The usefulness of such integration is 2-fold. First of all it creates a framework which generates a good deal of class discussion because it counter poses different sustainability perspectives with the 'business-as-usual' thinking that underpins most teaching programs. Examining and contrasting the assumptions underlying each concept will assist students in developing critical and reflective thinking. The aim is not to convert them to any particular viewpoint, but rather to help them understand and articulate all the sides of the sustainability debate, including the technology one.

\section{References}

Bi Tony, H. (2005, November). Integrating sustainability into Chemical \& Biological Engineering curricula at UBC, AIChE Annual Meeting, Session TE011, Cincinnati.

Capdevila, I., Bruno, J., \& Jofre, L. (2002). Curriculum greening and environmental research co-ordination at the Technical University of Catalonia, Barcelona. Journal of Cleaner Production, 10(1), 25-32. doi: 10.1016/S0959-6526(01)00019-1.

Ferrer-Balas, D., Bruno, J., \& Sans, R. (2002). Experiences of curriculum greening at the Technical University of Catalonia in the frame of the environmental plan (1996-2001). Proceedings Engineering Education in Sustainable Development, Delft.

Foster, J. (2001). Education as sustainability. Environmental Education Research, 7(2), 153-165. doi: $10.1080 / 13504620120043162$. 
Gross, D. (2000). Human nature articles: Three questions on education for sustainable development vol. 5(2), GreenCom.

Huckle, J., \& Sterling, S. (1996). Education for sustainability. London: WWF \& Earthscan.

IUCN, WWF, \& UNEP. (1991). Caring for the earth. Oxford: Oxford University Press.

King, K. P. (2005). Bringing transformative learning to life. Malabar, FL: Krieger.

Leal Filho, W. (Ed.). (2000). Communicating sustainability. Frankfurt: Verlag Peter Lang.

Leal Filho, W., \& Pace, P. (2006). The UN Decade of education for sustainable development: Meeting the challenges or another missed opportunity? In E. I. Manolas (Ed.), Proceedings of the 2006 Naxos international conference on sustainable management and development of mountainous and island areas Vol. 1. Greece: Dept of Forestry and Management of the Environment \& Natural Resources, Democritus University of Thrace.

Marsall, J. D., \& Toffel, M. W. (2005). Framing the elusive concept of sustainability: a sustainability hierarchy. Environmental Science and Technology, 39(3), 673-682. doi:10.1021/es040394k.

Martin, E. G., \& Martin, C. (2006). Best practices in technology education. Illinois: Technical Foundation of America.

Moore, J. (2005a). Barriers and pathways to creating sustainability education programs: policy rhetoric and reality. Environmental Education Research, 11(5), 537-555. doi:10.1080/13504620500169692.

Moore, J. (2005b). Seven recommendations for creating sustainability education at the university level: A guide for change agents. International Journal of Sustainability in Higher Education, 6(4), 326-333. doi:10.1108/14676370510623829.

Mulder, K. F., \& De Werk, G. (2004). Engineering in sustainable development. NPT Procestechnologie, 11(1), 11-13.

O'Sullivan, A. D., \& Painter, D. (2007). Advancing Sustainability through University Academic Formation-Experience with a Professional Engineering Program. Available: http://www.pce.govt.nz/ projects/engineering.pdf.

Pace, P. (2000). Attitudes towards environmental education in the Maltese formal education system. In W. Leal Filho (Ed.), Communicating sustainability. Environmental education, communication and sustainability (Vol. 8). Peter Lang: Frankfurt am Main.

Pavlova, M. (2007). Some practical solutions for achieving the ideals of sustainability: A case study of a technology teacher education program. Paper presented at the 1st European Conference on Education for Sustainable Development, Orestiada-Soufli, Greece, 5-7 October 2007.

Schleicher, K. (1996). Environmental ethics. In W. Leal Filho, F. MacDermot \& J. Padgham (Eds.), Implementing sustainable development at university level. UK: European Research \& Training Centre on Environmental Education, University of Bradford.

Scoullos, M. J. (1998) (ed) Environment and society: Education and public awareness for sustainability. Proceedings of the Thessaloniki International Conference. (8-12 December 1997). UNESCO \& Government of Greece.

Seemann, K. (2003). Basic principles in holistic technology education. Journal of Technology Education, $14(2), 28-39$.

Smyth, J. C. (2002). Are educators ready for the next earth summit? millennium papers series, issue 6. London: Stakeholder Forum for Our Common Future.

Tal, T. (2005). Implementing multiple assessment modes in an interdisciplinary environmental education course. Environmental Education Research, 11(5), 575-601. doi:10.1080/13504620500169767.

Tilbury, D. (1995). Environmental education for sustainability: Defining the new focus of environmental education in the 1990s. Environmental Education Research, 1(2), 195-212. doi:10.1080/1350462 950010206.

UNCED (United Nations Conference on Environment, Development). (1992). The United Nations conference on environment and development: A guide to agenda 21. Switzerland: UN Publications Office, Geneva.

UNEP. (1987) Connect Vol. XII, No. 3. September 1987.

UNESCO. (1980). Environmental education in the light of the Tbilisi conference. France: UNESCO.

UNESCO. (1997). Educating for a sustainable future: A transdisciplinary vision for concerted action. Paris: UNESCO.

UNESCO. (2005). Report by the director-general on the United Nations decade of education for sustainable development: International implementation scheme and UNESCO's contribution to the implementation of the decade. Paris: UNESCO.

UNESCO-UNEP. (1988). International strategy for action in the field of environmental education and training for the 1990s. Paris/Nairobi: UNESCO - UNEP.

United Nations. (1992). The UN conference on environment and development: A guide to agenda 21. Geneva: UN Publications Service. 
van Matre, S. (1990). Earth education: A new beginning. West Virginia: Institute of Earth Education.

Williams, P. J., \& Keirl, S. (2001). The teaching and learning of technology in australian primary and secondary schools. Paper presented at the IDATER (International Conference on Design and Technology Educational Research) 2001 Conference. Loughborough: Loughborough University. 